\title{
ANALISIS KEMAPUAN PENYELESAIAN SOAL MATEMATIKA BERORIENTASI PISA DALAM KONTEN PERUBAHAN DAN HUBUNGAN PADA SISWA SMP
}

\author{
Sutama, Sofia, M Novitasari \\ Universitas Muhammadiyah Surakarta \\ Email: sutama@ums.ac.id
}

\begin{abstract}
This research aims to describes the process of problem solving question of PISA in students. This research use a qualitative of research methods. The subject of this research grade VIII A SMP Negeri 1 Teras amounted to 28 students. Data collection techniques are used tests, interviews, and documentation method. In this research the validity of data using triangulation techniques to compare test results data, interviews, and documentation. Quantitative data analysis techniques using whereas reduction, serving until the conclusion of the withdrawal measures adapted to the Polya. The results of this research were obtained conclusions high-capable Students can meet all the indicators in the settlement of the question of maximum, medium and low skilled students not consistent in performing the stages of completion of a matter so that insufficient.
\end{abstract}

Keywords: problem solving; polya; mathematics; PISA

\begin{abstract}
Abstrak. Penelitian ini bertujuan untuk mendeskripsikan proses penyelesaian masalah soal PISA pada siswa. Penelitian ini menggunakan metode kualitatif. Subjek penelitian ini siswa kelas VIII A SMP Negeri 1 Teras berjumlah 28 siswa. Teknik pengumpulan data yang digunakan adalah metode tes, wawancara, dan dokumentasi. Pada penelitian ini keabsahan data menggunakan teknik triangulasi dengan membandingkan data hasil tes, wawancara, dan dokumentasi. Teknik analisis data kuantitatif menggunakan reduksi, penyajian hingga penarikan kesimpulan disesuaikan dengan langkah-langkah Polya. Hasil penelitian ini diperoleh kesimpulan siswa berkemampuan tinggi dapat memenuhi semua indikator dalam penyelesaian soal secara maksimal, siswa berkemampuan sedang dan rendah tidak konsisten dalam melakukan tahapan penyelesaian soal sehingga kurang maksimal.
\end{abstract}

Kata kunci: penyelesaian soal, polya, matematika, PISA

\section{Pendahuluan}

Pada era globalisasi seperti ini, dalam menghadapi Masyarakat Ekonomi Asean (MEA) kita dituntut untuk menjadi orang yang memiliki Sumber Daya Manusia (SDM) yang berkualitas. Itu artinya kita harus memiliki kemampuan berpikir yang kritis, logis, sistematis, kreatif, dan memiliki kemampuan untuk bekerja sama secara efektif. Untuk meningkatkan kualitas Sumber Daya Manusia (SDM) maka salah satu hal yang mempengaruhi adalah pendidikan. Untuk meningkatkan kualitas pendidikan maka dapat dimulai dengan peningkatan kualitas pembelajarannya. Hal ini bisa dilakukan dengan membuat susunan tujuan pembelajaran yang tepat terlebih dahulu.

Matematika merupakan ilmu pengetahuan yang sangat penting dan sangat berperan dalam ilmu pendidikan. Hal ini dikarenakan banyaknya aktivitas sehari-hari yang menggunakan ilmu matematika. Hanya saja 
pada saat ini proses pembelajaran matematika di sekolah, rata-rata siswa hanya menerima soal-soal prosedural yang hanya menunjang untuk kesuksesan ujian nasional. Menurut Maharani danKurniasari(2016) soal prosedural adalah soal yang untuk menyelesaikannya membutuhkan jawaban secara runtut dan algoritmik. Selain itu soal prosedural dapat diselesaikn dengan menggunakan berbagai macam media diantaranya geogebra maupun kalkulator.

Dalam melakukan kehidupan seharihari kita tidak bisa terlebas dari masalah. Perbedaaan kemampuan yang dimiliki oleh setiap individu akan menjadi dasar bagaimana individu tersebut mampu menyelesaikan sebuah masalah. Pemahaman yang berbeda antar individu satu dengan individu lainnya tersebut yang akan menjadikan perbedaan dalam menyelesaikan masalah yang dihadapi. Dalam menyelesaikan masalah, siswa yang berkemapuan pemahaman yang tinggi maka siswa tersebut juga memiliki kemampuan penyelesaian yang tinggi. Begitu pula sebaliknya siswa yang berkemampuan pemahaman rendah maka kemampuan penyelesaian siswa tersebut juga rendah. Akan tetapi untuk siswa berkemampuan pemahaman yang sedang, maka ini akan sulit didefinisikan.

Selain itu dalam menyelesaikan soal pemecahan masalah matematika, kemampuan setiap anak atau individu apabila dilihat dari jenis kelamin individu yaitu laki-laki dan perempuan akan berbeda-beda. Dimana dasar kemampuan laki-laki itu pada penalaran dan perempuan pada ketelitian dan kecermatan dalam melakukan penyelesaian soal. Hal ini sesuai dengan Anggraei (2018) bahwa kemampuan pemecahan masalah matematika subjek perempuan lebih baik dibandingkan subjek laki-laki. Hal ini tercermin dari hasil perolehan rata-rata skor benar setiap indikator yang menunjukkan bahwa subjek perempuan memiliki rata-rata lebih tinggi dibanding subjek laki-laki. Hal tersebut dipengaruhi oleh manajemen waktu subjek perempuan yang lebih baik dibandingkan subjek lakilaki, dimana dalam melakukan penyelesaian subjek perempuan cenderung melewati terlebih dahulu langkah penyelesaian atau soal yang dianggap sulit untuk selanjutnya mengerjakan terlebih dahulu soal lainnya. Akan tetapi, untuk hal lainnya tidak terdapat perbedaan yang mendasar antara subjek perempuan dan laki-laki dalam menyelesaikan soal pemecahan masalah matematika. PISA (Programme for International Student Assessment) adalah penilaian internasional yang mengukur kinerja anak usia 15 tahun dalam membaca keaaksaraan, literasi matematika, dan literasi sains. Diatur oleh Organisation for Economic Cooperation and Development (OECD), yaitu sebuah organisasi antar pemerintah dari 34 negara anggota. PISA pertama kali dilaksanakan pada tahun 2000 dan dilaksanakan setiap 3 tahun. Dari beberapa negara yang ikut berpartisipasi dalam PISA, Indonesia menjadi satu diantaranya. Hasil studi PISA dapat digunakan sebagai salah satu ukuran untuk mengetahui ukuran kemampuan siswa dalam meyelesaikan masalah matematika. Menurut Wardani yang dikutip dalam (Aini dan Siswono:2014) mengemukakan bahwa penyebab dari rendahnya kemampuan siswa dalam meyelesaikan atau memecahkan masalah khususnya yang berorientasi PISA dikarenakan siswa tidak terbiasa dalam melakukan proses menyelesaikan masalah dengan tepat dan benar. Proses pemecahan masalah yang benar yaitu melalui beberapa tahapan diantaranya memahami masalah terlebih dahulu, merencanakan apa yang akan dilakukan untuk memecahkan masalah tersebut, selanjutnya melaksanakan pemecahan masalah. Serta tidak lupa untuk mengecek kembali hasil pemecahan masalah. Hal ini bisa terlihat berdasarkan hasil survei internasional yang dilakukan oleh PISA, Indonesia menempati urutan tujuh terbawah dari seluruh negara yang menjadi anggota.

Soal PISA mempunyai beberapa cakupan materi, diantara dibagi menjadi empat konten yang masing masing kontennya memuat materi sendiri-sendiri. Salah satu konten PISA adalah konten perubahan 
dan hubungan yang di dalamnya berkaitan dengan pokok pelajaran aljabar dimana hubunganmatematika sering dinyatakan dalam persamaan atau hubunganyangbersifat umum, diantaranya penambahan, pengurangan, perkalian, danpembagian.

Oleh karena beberapa hal di atas, maka peneliti tertarik untuk melakukan penelitian tentang kemampuan siswa dalam proses menyelesaiakan soal berorientasi PISA dengan konten perubahan dan hubungan pada siswa SMP. Tujuan penelitian ini adalah untuk menganalisis perbedaan kemampuan proses penyelesaian soal matematika beroientasi PISA dengan konten perubahan dan hubungan pada siswa ditinjau dari gender.

\section{Metode Penelitian}

Penelitian yang dilakukan merupakan penelitian kualitatif yang menggunakan desain etnografi. Inti dari etnografi adalah upaya makna tindakan dari kejadian yang menimpa siswa yang ingin kita pahami.Sampel pada penelitian ini terdiri dari satu kelas, yaitu kelas VIII A sebagai kelas sampel dengan jumlah 28 siswa yang terdiri dari 6 siswa laki-laki dan 22 siswa perempuan. Selain itu peneliti mengambil kelas sampel lain yang digunakan untuk kelas uji coba yaitu kelas VIII D dengan jumlah 31 siswa.

Pengujian intrumen menggunakan uji validitas yang menggunakan rumus korelasi Product Moment danuji reliabilitas tesmenggunakan rumus Cronbach's Alpha (Teknik analisis data pada penelitian ini menggunakan metode alur dengan tahapanreduksi, penyajian dan menarik kesimpulan yang disesuaikan dengan langkahlangkah polya.

\section{Hasil dan Pembahasan}

Peneliti menggunakan dua kelas dalam melakukan penelitian. Satu kelas sebagai kelas sampel yaitu kelas VIII A yang berjumlah 32 siswa, akan tetapi pada saat dilakukan penelitian terdapat 4 siswa tidak hadir. Dengan demikian tersisa 28 siswa. Selain itu peneliti menggunakan satu kelas lain yaitu kelas VIII D yang berjumlah 31 siswa sebagai kelas uji coba. Dari hasil tes uji coba pada siswa kelas VIII D tersebut kita akan mendapatkan soal-soal yang valid yang kemudian diujikan pada siswa kelas VIII A melalui uji validitas dan realibilitas soal tes. Dari hasil jawaban siswa kelas VIII A inilah yang nantinya akan digunakan sebagai instrumen untuk mengetahui kemampuan siswa, menganalisis proses penyelesaian siswa dalam menyelesaikan soal matematika PISA.

Selanjutnya peneliti melakukan analisis proses penyelesaian soal matematika berorientasi PISA dalam konten perubahan dan hubungan. Dari hasil pekerjaan siswa diambil 9 siswa masing-masing 3 yang di kategorikan berkemampuan tinggi, sedang, dan rendah. Penentuan kategori siswa ditentukan dengan pengkategorian seperti pada Tabel 1. Dari tiga kategori tersebut masing masing dilakukan analisis penyelesaian soal.

Tabel 1. Kategori Tingkat Kemampuan Siswa

\begin{tabular}{lccc}
\hline \multicolumn{1}{c}{ Skor } & \multicolumn{2}{c}{ Frekuensi } & Kategori \\
\hline$x \geq 90,45$ & 13 & $46,4 \%$ & Tinggi \\
$72,26<x<90,45$ & 6 & $21,4 \%$ & Sedang \\
$x \geq 72,26$ & 9 & $32,2 \%$ & Rendah \\
\hline \multicolumn{1}{c}{ Jumlah } & 28 & $100 \%$ & \\
\hline
\end{tabular}




\section{Siswa dengan kemampuan matemmatika tinggi}

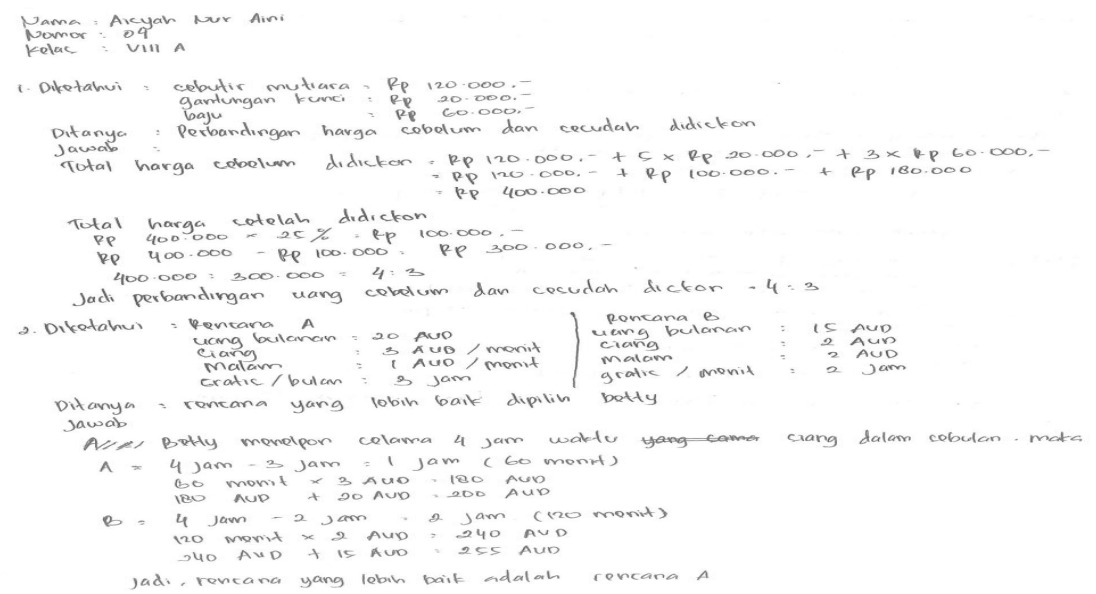

Gambar 1. Jawaban S1 Soal Nomor 2

Berdasarkan dari hasil jawaban siswa S1 : Agak usah bu pada Gambar 1, menunjukan S1 telah mampu P : Susahnya dimana?

menuliskan apa yang diketahui dan yang S1 : Awalnya saya bingung bu baca datanya

ditanyakan pada soal sehingga memenuhi $\mathrm{P}$ : Bagaimana langkah-langkah kamu untuk indikator memahami masalah. Siswa S1 mampu mengerjakan soal nomor 2?

menyusun strategi dan melksanakan strategi S1 : Jadi saya harus mencari biaya masingdengan tepat untuk melakukan penyelesaian masing rencana nya dulu bu, baru nantinya dibandingkan mana yang lebih murah

kembali dengan menuliskan kesimpulan jawaban. Dengan demikian S1 memenuhi semua indikator penyelesaian soal Berikut adalah data wawancara peneliti dengan S1.

$\mathrm{P}$ : Kalo soal nomor 2 ini gimana? Mudah kesulitan. juga?

\section{Siswa dengan kemampuan matemmatika sedang}

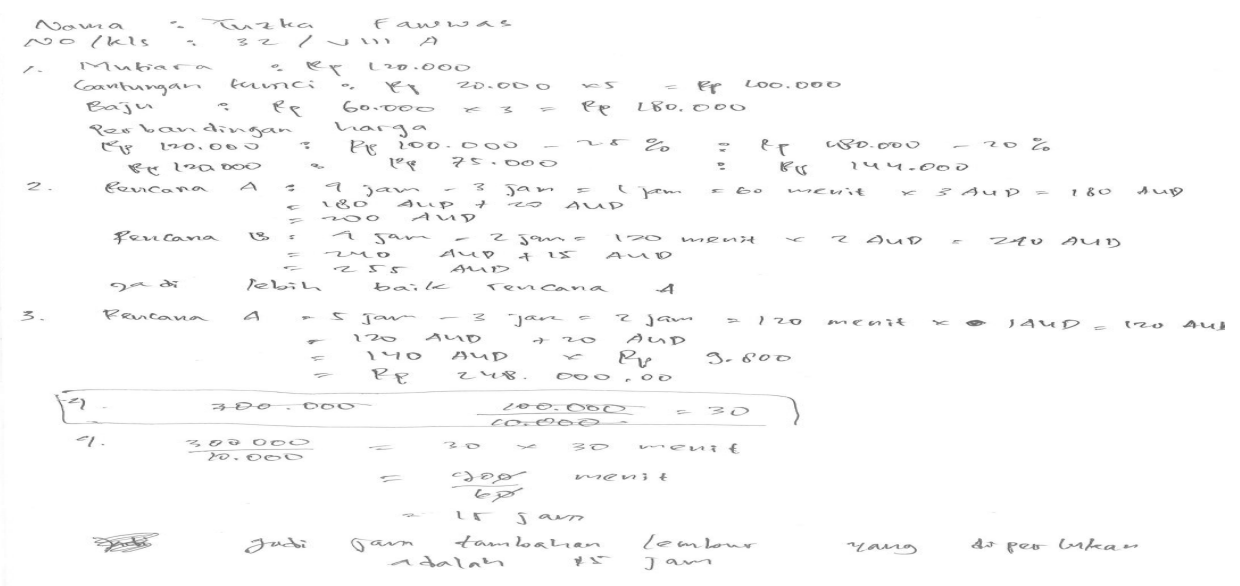

Gambar 2. Jawaban S5 Soal Nomor 4 
Berdasarkan dari hasil jawaban siswa pada Gambar 2, menunjukan S5 tidak mampu menuliskan apa yang diketahui dan yang ditanyakan pada soal sehingga tidak memenuhi indikator memahami masalah. Siswa S5 mampu menyusun strategi dan melksanakan strategi dengan tepat untuk melakukan penyelesaian soal. Serta S5 telah memenuhi indikator menguji kembali dengan menuliskan kesimpulan jawaban. Dengan demikian S5 tidak memenuhi semua indikator penyelesaian soal Berikut adalah data wawancara peneliti dengan S5.

$\mathrm{P}$ : Apa yang ditanyakan dari soal nomor 4 ?

S5 : Jam tambahan supaya mendapat honor Rp.300.000,00 bu

$\mathrm{P}$ : Kenapa tidak ditulis dijawaban?

S5 : Enggak bu, soalnya buru-buru takut waktunya habis

$\mathrm{P}$ : Mengerjakan sendiri?

S5 : Iya bu

\section{Siwa dengan kemampuan matematika rendah}

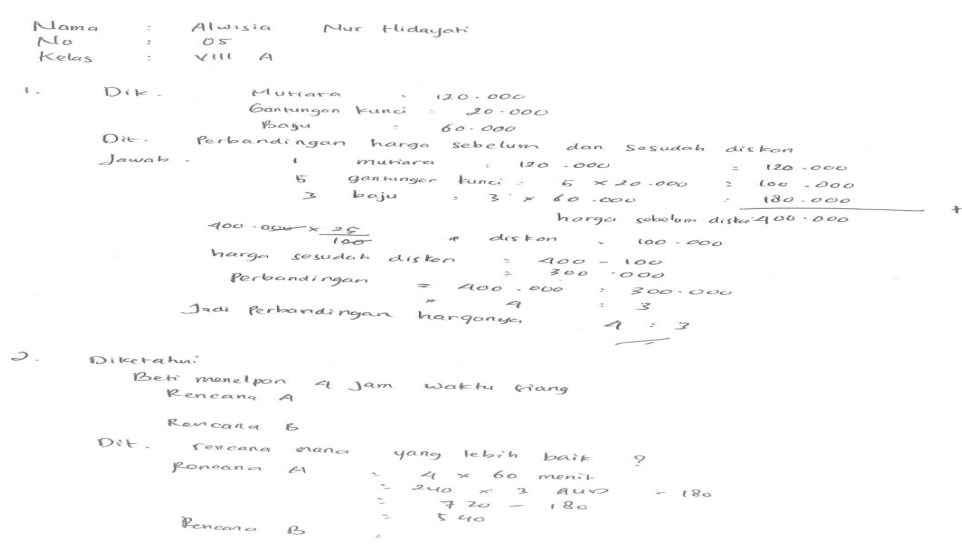

Gambar 3. Jawaban S8 Soal Nomor 2

Berdasarkan dari hasil jawaban siswa pada Gambar 3, menunjukan S8 hanya mampu menuliskan apa yang diketahui dan yang ditanyakan pada soal secara garis besarnya saja. Siswa S5 mampu menyusun strategi akan tetapi tidak mampu melaksanakan strategi dengan tepat untuk melakukan penyelesaian soal. Serta S8 tidak memenuhi indikator menguji kembali dengan menuliskan kesimpulan jawaban. Dengan demikian S8 tidak memenuhi semua indikator penyelesaian soal. Berikut adalah data wawancara peneliti dengan S5.

$\mathrm{P}$ : Ini kenapa nomor 2 ngga kamu selesaikan?

S8 : Bingung bu

$\mathrm{P}$ : Yang diketahui dari soal nomor 2 apa?

S8 : Ada dua rencana menelpon, terus suruh mencari mana yang lebih murah bu
$\mathrm{P}$ : Kenapa tidak kamu tulis secara rinci masing-masing rencana?

S8 : Lupa bu

$P$ : Coba ini dilihat gratisnya itu waktunya apa biayanya?

S8 : Waktu bu

$P \quad$ : Berarti ini kamu salahnya dimana?

S8 : Harusnya dikalikan sala biayanya dulu baru dikurangi ya bu?

$P$ : Nah itu kamu paham

Dari data hasil wawancara menunjukan bahwa S8 tidak mampu memenuhi semua indikator penyelesaian soal dikarenakan kurangnya ketelitian dalam memahami soal.

Dengan demikian siswa berkemampuan tinggi yang terdiri dari siswa laki-laki maupun siswa perempuan dapat memenuhi semua indikator dalam penyelesaian soal secara 
maksimal, siswa berkemampuan sedang dan rendah tidak konsisten dalam melakukan tahapan penyelesaian soal sehingga kurang maksimal. Hal ini senada dengan penelitian Putri, Susanto, dan Kurniati (2015) yang menyimpulkan bahwa siswa berkemampuan tinggi memiliki keterampilan yang optimal dalam mengontrol dan menyelesaikan setiap permasalahan. Siswa berkemampuan sedang cukup baik dalam mengontrol dan menyelesaikan setiap permasalahan meskipun pada beberapa permasalahah siswa berkemampuan sedang kurang optimal dalam menggunakan keterampilan metakognitifnya. Siswa berkemampuan rendah memiliki keterampilan metakognitif yang kurang optimal dalam mengontrol dan menyelesaikan permasalahan. Hal ini senada dengan penelitian Dewi, Asyar, dan Kamid (2013) yang menyimpulkan bahwa siswa berkemampuan rendah tidak dapat menyelesaikan masalah dengan benar pada langkah melaksanakan rencana pemecahan masalah dan mengecek kembali hasil pemecahan masalah. Hal itu juga didukung dari penelitian yang dilakukan Stoet dan Geary (2013) ini menyimpulkan bahwa peneliti tidak menemukan pengaruh perbedaan jenis kelamin dalam kemampuan matematika diantara siswa yang berkinerja paling rendah. Sebaliknya, perbedaan jenis kelamin berpengaruh besar terhadap kemampuan matematika diantara siswa yang berkinerja tinggi. Implikasinya adalah jika pembuat kebijakan memutuskan perubahan dalam pengaruh perbedaan jenis kelamin diinginkan, pendekatan yang berbeda akan diperlukan untuk mencapai ini.

Selain itu dilakukan wawancara dengan kesembilan sampel untuk memeroleh informasi secara mendalam untuk mengetahui penyebab siswa kurang tepat dalam melakukan penyelesaian soal diantaranya: 1) pada indikator memahami masalah siswa kurang terbiasa menuliskan informasi yang terdapat pada soal, selain itu terdapat beberapa siswa yang kurang memahami soal. 2) pada indikator menyususn rencana siswa melakukan kekeliruan dalam menyusun strategi yang tepat. 3) pada indikator melaksanakan rencana siswa tidak teliti dan melakukan kesalahan perhitungan sehingga tidak mendapat jawaban yang tepat. 4) pada indikator menguji kembali siswa tidak terbiasa dalam menuliskan kesimpulan dikarenakan terburu-buru. Didukung penelitian Widodo (2013) menyatakan indikator kesalahan membuat rencana pemecahan masalah meliputi tidak mengetahui kecukupan dan keperluan syarat dari suatu masalah dan tidak menggunakan semua informasi yang telah dikumpulkan.

\section{Kesimpulan}

Siswa laki-laki dan siswa perempuan berkemampuan tinggi dapat memenuhi semua indikator dalam penyelesaian soal secara maksimal, sedangkan siswa laki-laki maupun siswa perempuan siswa berkemampuan sedang dan rendah tidak konsisten dalam melakukan tahapan penyelesaian soal sehingga kurang maksimal. Selain itu faktor penyebab siswa kurang tepat dalam menyelesaikan soal adalah siswa tidak terbiasa menuliskan informasi soal, siswa kurang cermat dalam menentuka strategi penyelesaian, ketidaktelitian siswa dalam melakukan perhitungan, serta kurang tepat dalam menuliskan kesimpulan.

Berbagai ucapan terima kasih kami sampaikan kepada berbagai pihak yang telah mendukung kegiatan penelitian ini. Ucapan terima kasih kami sampaikan kepada Direktorat Riset dan Pengabdian Masyarakat Direktorat Jenderal penguatan Riset dan Pengembangan Kementerian Riset, Teknologi, dan Pendidikan Tinggi yang telah membantu dalam pendanaan biaya penelitian multi tahun melalui Hibah Penelitian Tim Pascasarjana. Ucapan terima kasih kami sampaikan kepada Direktur Sekolah Pascasarjana dan Ketua Lembaga Penelitian UMS beserta stafnya, yang telah memberikan fasilitas dan dorongan sehingga kami bisa melakukan penelitian. ucapan terima kasih juga kami sampaikan kepada kepala Dinas Pendidikan, para kepala dan guru matematika SMP Kabupaten Sukoharjo Jawa Tengah, yang telah membantu proses penelitian sehingga berjalan sesuai perencanaan. 


\section{Daftar Pustaka}

Aini, R.N.,\&Siswono. (2014). Analisis Pemahaman Siswa SMP dalam Menyelesaikan Masalah Aljabar pada PISA. Jurnal Ilmiah Pendidikan Matematika, 3(2).

Anggraeni, R. (2018). Kemampuan Pemecahan Masalah Matematik Siswa SMP pada Materi Lingkaran Berbentuk Soal Kontekstual Ditinjau dari Gender. Nurmeracy, 5(1).

Dewi, Sri, Rayandra Asyar, dan Kamid. (2013). Analisis Pemecahan Masalah Matematika pada Siswa Tipe Visual Berbasis Realistic Mathematics Education (RME) di Kelas VIII SMP N 2 Kota Jambi. Tekno-Pedagogi, 3(2): 42-51.

Maharani, R.\& Kurniasari, I. (2016). Kemampuan Literasi Matematika Siswa Kelas X SMAN 1 Mojo dalam Menyelesaikan Soal Model PISA Ditinjau dari Kemampuan Matematika. Jurnal Ilmiah Pendidikan Matematika, 3(5).

Putri, Riandani Sarwindah, Susanto, Dian Kurniati. 2015. “Analisis Keterampilan Metakognitif Siswa dalam Menyelesaikan Masalah Matematika Berbasis Polya Subpokok Bahasan Garis dan Sudut Kelas VII-C di SMP Negeri 1 Genteng Banyuwangi”. Artikel Ilmiah Mahasiswa 2 (1).

Stoet, G.\&Geary, D.C. (2013). Sex different in mathematics and readingachievement are inversely related : within-and- across-nation assessment of 10 yea $r$ of PISA data. PLOS ONE, 8(3).

Sutama, 2016.Darurat Pembelajaran Matematika: Guru Matematika Profesional Untuk Menyiapkan Generasi Emas. Artikel Seminar Nasional Pendidikan Matematika FKIP UMS, 15 Mei 2016.

Sutama. 2015. Budaya kerja guru intelektual transformatif:Perubahan refleksi dan aksi guru matematika dalam mengahadapi PPG, artikel Seminar Nasional Pend. Matematika: Pemberdayaan Guru Intelektuan Transformatif Menghadapi PPG Surakarta, 10 Mei 2015.

Sutama. 2012. "Metode Penelitian Pendidikan (Kuantitatif, Kualitatif, PTK, R\&D). Surakarta: Fairuz Media.

Sutama. 2011. "Pengelolaan Pembelajaran Matematika Berbasis Aptitude Treatment Interaction”. Pidato Pengukuhan Guru Besar. Surakarta: Muhammadiyah University Press.

Sutama, Narimo, S., dan Haryoto. 2013. "Contextual Math Learning Based on Lesson Study Can Increase Study Communication”.International Journal of Education. Vol. 5, No. 4, 48-60.

Sutama, Narimo, S., dan Haryoto. 2012. "Mathematics Learning Management at Elemantary School Post Merapi Eruption”. International Journal of Education. Vol. 4, No. 4, $192-$ 203.

Widodo, Sri Adi. (2013). Analisis Kesalahan dalam Pemecahan Masalah Divergensi Tipe Membuktikan pada Mahasiswa Matematika. Jurnal Pendidikan dan Pengajaran, 46 (2): 106-113. 